\title{
Pengambilan Keputusan Memilih Sekolah Dengan Metode AHP
}

\author{
Narti $^{1}$, Sriyadi ${ }^{2}$, Nur Rahmayani ${ }^{3}$, Mahmud Syarif $^{4}$ \\ ${ }^{1}$ STMIK Nusa Mandiri \\ e-mail: narti.nrx@nusamandiri.ac.id \\ ${ }^{2}$ Universitas Bina Sarana Informatika \\ e-mail: sriyadi.sry@bsi.ac.id \\ ${ }^{3}$ STMIK Nusa Mandiri \\ e-mail: nrahmayani18@gmail.com \\ ${ }^{3}$ Universitas Bina Sarana Informatika \\ e-mail:mahmud.may@bsi.ac.id
}

\begin{abstract}
Abstrak
Setiap orang tua pasti ingin anaknya mendaftar pada sekolah yang tepat. Orang tua tidak ingin salah pilih dalam memilihkan sekolah untuk anak-anaknya. Dalam memilih sekolah yang baik dan tepat tentunya bukanlah suatu hal yang mudah, hal tersebut disebabkan karena banyaknya pertimbangan-pertimbangan yang dilakukan untuk mendapat suatu pilihan sekolah yang tepat, serta banyaknya pilihan sekolah yang membingungkan masyarakat baik siswa maupun orang tuanya. Adanya pendukung keputusan ini dapat menjadi solusi untuk memberikan pertimbangan dalam membantu masyarakat pada proses pemilihan sekolah. Metode Analytical Hierarchy Process (AHP) merupakan metode yang memiliki struktur yang berhirarki serta memberikan kemudahan dalam menyederhanakan suatu permasalahan dari kriteria yang kompleks dengan berbagai pilihan alternatif yang ada, sehingga dapat mempercepat proses pengambilan keputusan dalam pemilihan sekolah. Metode AHP ini mampu menghasilkan hasil yang lebih konsisten serta yang dihasilkan adalah berdasarkan urutan ranking dari setiap alternatif yang ada. Hasil perhitungan metode AHP ini terdapat empat kriteria yang menjadi tolak ukur dalam melakukan pemilihan sekolah yaitu, biaya, kualitas sekolah, tujuan akhir lulusan, serta bakat dan minat. Hasil akhir dari pengolahan data dan pengujian metode AHP didapatkan bahwa Sekolah Menengah Atas (SMA) lebih unggul 0,373 atau 37,3\% sedangkan Sekolah Menengah Kejuruan (SMK) 0,370 atau 37,0\%, Madrasah Aliyah (MA) 0,257 atau $25,7 \%$.
\end{abstract}

Kata Kunci: AHP, Sekolah, Memilih, Keputusan

\begin{abstract}
Every parent would want to move to the right school. Parents do not want to choose in choosing schools for children. In choosing a good and right school to answer an easy matter, it relates to the judgments made to get an appropriate school choice, as well as adding school choices that allow the community both parents and parents. The existence of supporters of this decision can be a solution to provide assistance to the community in the school selection process. The Analytical Hierarchy Process (AHP) method is a method that has a hierarchical structure and makes it easy to simplify a problem from complex criteria to various alternative choices that exist, so that it can accelerate the decision making process in school selection. This AHP method produces better results as well as those produced based on the ranking order of each alternative. The results of the calculation of the AHP method are related to four criteria which are the benchmarks in conducting school selection, namely, costs, quality of the school, the ultimate goal of the competition, and talents and interests. The final results of data processing and testing methods obtained by Senior High School (SMA) are superior to 0.373 or $37.3 \%$ while Vocational High School (SMK) is 0.370 or $37.0 \%$, Madrasah Aliyah (MA) is 0.257 or $25.7 \%$.
\end{abstract}

Keywords: AHP, School, Choosing, Decision 


\section{Pendahuluan}

Pendidikan formal merupakan salah satu kebutuhan dalam memperoleh ilmu untuk mewujudkan cita-cita dan keinginan melalui suatu pengajaran. Pendidikan menjadi hal terpenting bagi masyarakat khususnya Indonesia, karena dengan adanya pendidikan, dapat menentukan kemajuan dan berkembangnya suatu negara. Pendidikan di Indonesia dimulai dari Sekolah Dasar (SD), Sekolah Menengah Pertama (SMP)/Madrasah Tsanawiyah (MTs), Sekolah Menengah Atas (SMA)/Sekolah Menengah Kejuruan (SMK)/Madrasah Aliyah (MA) hingga Perguruan Tinggi. Dalam menempuh pendidikan dapat mempengaruhi masyarakat dalam mengambil keputusan dari berbagai pilihan alternatif yang ada, seperti dalam pemilihan sekolah baik dari sekolah tingkat dasar hingga perguruan tinggi yang mana pemilihan sekolah ini akan membantu dalam pembentukan kepribadian juga sikap serta akan mempengaruhi masa depan bagi anaknya.

Dalam memilih sekolah yang baik dan tepat tentunya bukanlah suatu hal yang mudah, hal tersebut disebabkan karena banyaknya pertimbangan-pertimbangan atau kriteria yang harus diperhatikan dalam memilih sekolah khususnya dalam sekolah lanjutan tingkat atas, serta banyaknya pilihan sekolah yang membingungkan masyarakat baik siswa maupun orang tuanya. Kemudian masyarakat cenderung memilih sekolah karena mengikuti temanteman anaknya.

Kelurahan Kutabaru merupakan salah satu pembagian wilayah dari Kecamatan Pasarkemis, Kabupaten Tangerang yang memiliki $12 \mathrm{RW}$, yang mana setiap RW memiliki beberapa RT dan terdapat 8.573 kepala keluarga di wilayah Kelurahan kutabaru.

Dalam memilih keputusan, adanya pendukung keputusan ini dapat menjadi solusi untuk memberikan pertimbangan alternatif dalam membantu masyarakat pada proses penentuan atau pemilihan sekolah. Dari berbagai metode yang ada, penulis memilih menggunakan metode Analytical Hierarchy Process (AHP) dalam pengambilan keputusan pemilihan sekolah. Metode ini dipilih karena memiliki struktur yang berhirarki serta memberikan kemudahan dalam menyederhanakan suatu permasalahan dari kriteria yang kompleks dengan berbagai pilihan alternatif yang ada, sehingga dapat mempercepat proses pengambilan keputusan dalam pemilihan sekolah. Metode Analytical Hierarchy Process (AHP) ini mampu menghasilkan hasil yang lebih konsisten serta yang dihasilkan adalah berdasarkan urutan ranking dari setiap alternatif yang ada.

(Suryadi \& Ramdhani, 2017)Pada dasarnya pengambilan keputusan adalah suatu pendekatan sistematis pada hakekat suatu masalah, pengumpulan fakta-fakta, penentuan yang matang dari alternatif yang dihadapi, dan pengambilan tindakan yang menurut perhitungan merupakan tindakan yang paling tepat. Pembuat keputusan kerap kali dihadapkan dengan kerumitan dalam lingkup pengambilan keputusan dengan data yang banyak. Untuk suatu kepentingan sebagian besar pembuat keputusan dengan mempertimbangkan manfaat yang dihadapkan pada suatu keharusan untuk mengandalkan seperangkat sistem yang mampu memecahkan masalah efisien dan efektif.

(Akmaludin, 2015) Penggunaan metode Analytic Hierarchy Process (AHP) banyak dari berbagai kalangan akademisi yang menggunakan metode ini, hingga menerapkannya sampai pada implementasi dalam kehidupan sehari-hari, yang sangat diperhatikan begitu banyaknya pendekatan yang digunakan oleh para pengguna metode AHP, khususnya dalam hal seleksi terhadap sesuatu fenomena.

\section{Metode Penelitian}

Dalam penelitian ini metode yang digunakan adalah AHP (Analytical Hierarchy Process).

(Hadianti \& Mubarok, 2017) "AHP (Analytical Hierarchy Process) adalah suatu teori umum tentang pengukuran yang digunakan untuk menemukan skala rasio, baik dari perbandingan berpasangan yang diskrit maupun kontinyu".

Menurut Tominanto dalam (Narti, 2017) menyimpulkan bahwa:

AHP adalah sebuah metode memecah permasalahan yang komplek atau rumit dalam situasi yang tidak terstruktur menjadi bagian-bagian komponen. Mengatur bagian atau variabel ini menjadi suatu bentuk susunan hierarki, kemudianmemberikan nilai numerik untuk penilaian subjektif terhadap kepentingan 
relatif dari setiap variabel dan mensintesis penilaian untuk variabel mana yang memiliki prioritas tertinggi yang akan mempengaruhi penyelesaian dari situasi tersebut.

AHP bertujuan untuk menyusun prioritas dari berbagai alternatif pilihan yang ada. Terdapat 4 aksioma-aksioma menurut (Pratiwi, 2016), diantaranya yaitu:

1. Reciprocal Comparison artinya pengambilan keputusan harus memuat perbandingan dan menyatakan preferensinya.

2. Homogenityartinya harus dapat dinyatakan dalam skala terbatas atau elemen-elemenya dapat dibandingkan satu sama lain.

3. Independenceartinya mengasumsikan bahwa kriteria tidak dipengaruhi oleh alternatif-alternatif yang ada melainkan oleh objek keseluruhan.

4. Expectationartinya struktur hirarki diasumsikan lengkap.Menjelaskan kronologis penelitian, termasuk desain penelitian, prosedur penelitian (dalam bentuk algoritma, Pseudocode atau lainnya), bagaimana untuk menguji dan akuisisi data. Deskripsi dari program penelitian harus didukung referensi, sehingga penjelasan tersebut dapat diterima secara ilmiah.

Secara teknis dan pada dasarnya dalam metode AHP terdiri dari prinsipprinsip dasar dalam memahami AHP. Adapun prinsip dasar tersebut menurut (Basuki \& Andharini, 2016) yaitu:

1. Menyusun Hirarki

Persoalan yang akan diselesaikan, diuraikan menjadi unsur-unsurnya, yaitu kriteria dan alternatif, kemudian disusun menjadi struktur hirarki.

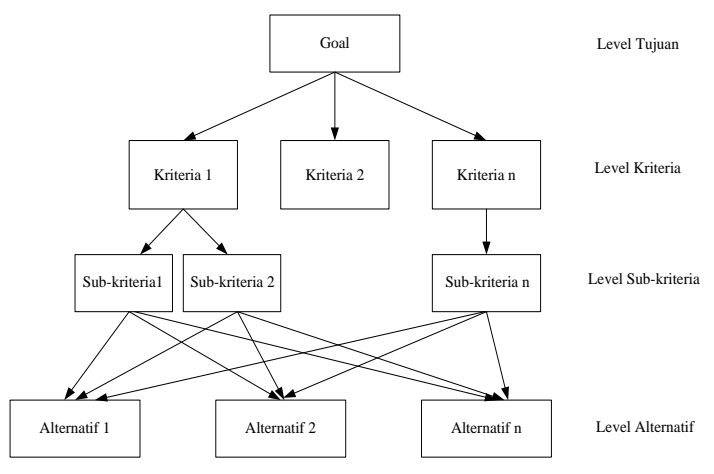

Gambar 1. Struktur Hirarki AHP

Sumber : ( Basuki \& Andharini, 2016)
2. Penilaian Kriteria dan Alternatif

Kriteria dan aternatif dinilai melalui perbandingan berpasangan. Untuk persoalan yang ada skala 1 sampai skala 9 adalah skala terbaik dalam mengekspresikan pendapat. Perbandingan dilakukan berdasarkan kebijakan pembuat keputusan dengan cara menilai tingkat kepentingan antara elemen yang satu dengan elemen yang lainnya.

Tabel 1. Skala Penilaian Perbandingan Berpasangan

\begin{tabular}{|c|c|c|}
\hline $\begin{array}{l}\text { Intensitas } \\
\text { Kepentingan }\end{array}$ & Keterangan & Penjelasan \\
\hline 1 & $\begin{array}{l}\text { Kedua elemen sama } \\
\text { pentingnya }\end{array}$ & $\begin{array}{l}\text { Dua elemen mempunyai } \\
\text { pengaruh yang sama besar } \\
\text { terhadap tujuan }\end{array}$ \\
\hline 3 & $\begin{array}{l}\text { Elemen yang satu sedikit } \\
\text { lebih penting daripada } \\
\text { elemen yang lainnya }\end{array}$ & $\begin{array}{l}\text { Pengalaman dan penilaian } \\
\text { sedikit menyokong satu } \\
\text { elemen dibandingkan } \\
\text { elemen lainnya }\end{array}$ \\
\hline 5 & $\begin{array}{l}\text { Elemen yang satu lebih } \\
\text { penting daripada elemen } \\
\text { yang lainnya }\end{array}$ & $\begin{array}{l}\text { Pengalaman dan penilaian } \\
\text { sangat kuat menyokong satu } \\
\text { elemen dibandingkan } \\
\text { elemen lainnya }\end{array}$ \\
\hline 7 & $\begin{array}{l}\text { Elemen yang satu jelas } \\
\text { lebih mutlakpenting } \\
\text { daripada yang lainnya }\end{array}$ & $\begin{array}{l}\text { Satu elemen yang kuat } \\
\text { disokong dan dominan } \\
\text { terlihat dalam praktek }\end{array}$ \\
\hline 9 & $\begin{array}{l}\text { Satu elemen mutlak } \\
\text { penting daripada elemen } \\
\text { lainnya }\end{array}$ & $\begin{array}{l}\text { Bukti yang mendukung } \\
\text { elemen yang satu terhadap } \\
\text { elemen lain memiliki tingkat } \\
\text { penegasan tertinggi yang } \\
\text { mungkin menguatkan }\end{array}$ \\
\hline $2,4,6,8$ & $\begin{array}{l}\text { Nilai-nilai antara dua nilai } \\
\text { pertimbangan- } \\
\text { pertimbangan } \\
\text { berdekatan }\end{array}$ & $\begin{array}{l}\text { Nilai ini diberikan bila ada } \\
\text { dua kompromi di antara dua } \\
\text { pilihan }\end{array}$ \\
\hline Kebalikan & \multicolumn{2}{|c|}{$\begin{array}{l}\text { Jika aktifitas } i \text { mendapat satu angka dibandingkan dengan } \\
\text { aktifitas } j \text {, maka } j \text { memiliki kebalikannya dibandingkan } \\
\text { dengan } i\end{array}$} \\
\hline
\end{tabular}

Sumber : (Suryadi \& Ramdhani 2016)

\section{Penentuan Prioritas}

Untuk setiap kriteria dan alternatif, perlu dilakukan perbandingan berpasangan. Nilai-nilai perbandingan relatif kemudian diolah untuk menentukan peringkat alternatif dari seluruh alternatif. Baik kriteria kualitatif maupun kuantitatif dapat dibandingkan sesuai dengan penilaian yang teah ditentukan untuk menghasilkan suatu bobot dan prioritas. Bobot atau prioritas ini dihitung dengan manipulasi matriks atau dengan penyelesaian matematik. 
4. Konsistensi Logis

Konsistensi logis menurut (Kusrini, 2016) memiliki dua makna. Pertama, objek-objek yag serupa bisa dikelompokkan sesuai dengan keseragaman dan relevansi. Kedua, menyangkut hubungan antar objek yang didasarkan pada kriteria tertentu. (Handayani, 2015) "Nilai rasio konsistensi harus 10\% atau kurang. Pada referensi yang lain menyebutkan bahwa hasil perhitungan nilai inkonsistensi antara 0 hingga 1 . Jika lebih dari $10 \%$, pertimbangan yang telah dibuat mungkin agak acak dan mugkin perlu untuk diperbaiki”.(Malik \& Haryanti, 2018) "Inkonsistensi ini dapat disebabkan oleh kesalahan memasukkan penilaian, kurangnya informasi, kurangnya konsentrasi, dunia nyata yang tidak selalu konsisten, atau model struktur hirarki yang kurang sesuai".

Ada beberapa tahapan dalam menyusun penelitian ini. Dalam tahap kesatu penulis memilih tema pengambilan keputusan dalam pemilihan sekolah, kemudian dilanjutkan dengan mengidentifikasi permasalahan yang terjadi di masyarakat dalam proses pemilihan sekolah yang nantinya akan dibuatkan rumusan masalah. Kemudian penulis melakukan studi pendahuluan untuk mengumpulkan beberapa informasi yang berkaitan dengan masalah yang akan diteliti serta menentukan metode untuk penyelesaiannya dan nantinya dari hasil tersebut dapat digunakan dalam penyusunan kerangka teori untuk menjawab permasalahan tersebut dengan merumuskan hipotesis. Permasalahan yang sedang diteliti akan dibuktikan kebenarannya melalui dugaan atau jawaban sementara yang disebut hipotesis. Selanjutnya menentukan sample penelitian serta berakhir pada penyusunan penelitian.

Dalam tahapan kedua penulis mengumpulkan data berdasarkan populasi yang telah ditentukan. Namun populasi dalam penelitian ini sangatlah luas sehingga penulis menggunakan sampel dari populasi tersebut. Kemudian ditentukan instrumen penelitian untuk mengukur variabel yang sedang diteliti. Instrumen yang digunakan berupa penyebaran kuesioner, observasi, serta wawancara. Setelah data sudah terkumpul dilakukan tahap analisis data untuk menjawab dari suatu rumasan masalah dan hipotesis menggunakan metode yang telah ditentukan dalam pengambilan keputusan kemudian disajikan dan diberikan pembahasan secara detail.

$\mathrm{Di}$ tahapan ketiga merupakan tahapan akhir yang mana setelah pembahasan dijelaskan, penulis menarik sebuah kesimpulan dari keseluruhan penelitian dan kemudian dilakukan penulisan laporan dari hasil penelitian itu sendiri.

Dikarenakan populasi yang akan diteliti sangatlah luas dan memakan biaya yang cukup besar serta waktu penelitian ini sangatlah terbatas maka penulis menggunakan sampel penelitian. Sampel merupakan bagian atau mewakili dari sebuah populasi. Dalam penelitian ini untuk mendapatkan data digunakan teknik sampling dalam pengambilan sampel, penulis menggunakan probability sampling. Menurut Sugiyono (2016:82) mengemukakan bahwa "Probability samping adalah teknik pengambilan sampel yang yang memberikan peluang yang sama bagi setiap unsur (anggota) populasi untuk dipilih menjadi anggota sampel". Teknik yang digunakan dalam probability sampling adalah teknik cluster sampling, karena sumber data yang akan diteliti sangat luas. Pada lingkungan kelurahan kutabaru terdapat $12 \mathrm{RW}$, maka sampel yang akan digunakan adalah 3 RW. Dari 3 RW ini akan dilakukan pemilihan lagi yaitu diambil setiap RW hanya dipilih sebanyak 2 RT. Selanjutnya penulis juga menggunakan teknik pengambilan sampel stratified random sampling dengan cara pendataan masing-masing RT berdasarkan latar belakang pekerjaan orang tua.

\section{Hasil dan Pembahasan}

Untuk memperoleh hasil data yang dibutuhkan dalam penelitiaan ini, peneliti melakukan penyebaran kuesioner kepada masyarakat yang mana dari hasil kuesioner tersebut akan diolah sehingga dapat dijadikan sebagai pemecah suatu masalah dalam hal pemilihan sekolah. Penyebaran kuesioner ini disebar sebanyak 35 kuesioner, namun hanya 30 kuesioner yang dapat diolah.

Dalam pengolahan hasil penelitian maka penulis menetapkan langkah-langkah penyelesaian dengan metode AHP diantaranya yaitu membuat hirarki, penilaian kriteria dan alternatif yaitu dengan 
cara membuat matriks perbandingan berpasangan, menentukan prioritas dan bobot, serta menguji konsistensi logis, kemudian ditentukan hasil akhir dari perhitungan

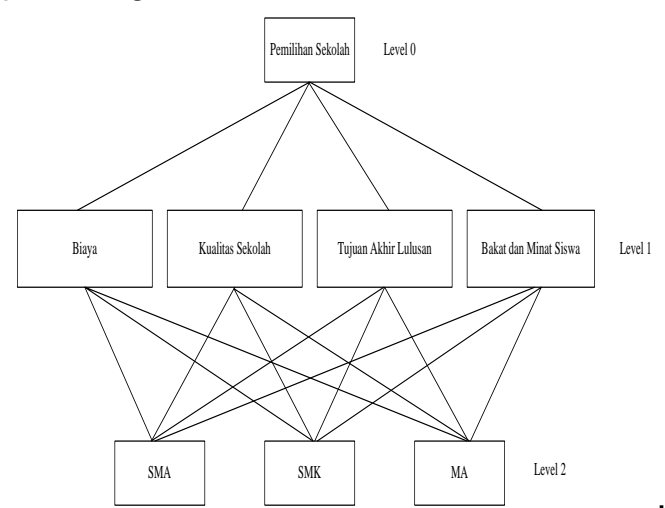

Gambar 2. Struktur Hirarki Pemilihan Sekolah

Tabel 2. Kriteria Utama

\begin{tabular}{|c|c|}
\hline Kriteria & Penjelasan \\
\hline Biaya & $\begin{array}{l}\text { Biaya yang menjadi pilihan } \\
\text { adalah biaya sekolah yang } \\
\text { terjangkau atau mahal. }\end{array}$ \\
\hline Kualitas Sekolah & $\begin{array}{l}\text { Kualitas yang dimaksud } \\
\text { adalah fasilitas sekolah, } \\
\text { lingkungan belajar, pengajaran } \\
\text { agama, penanaman nilai nilai } \\
\text { yang baik serta penerapan } \\
\text { kedisiplinan. }\end{array}$ \\
\hline $\begin{array}{c}\text { Tujuan Akhir } \\
\text { Lulusan }\end{array}$ & $\begin{array}{l}\text { Tujuan akhir lulusan yang } \\
\text { dimaksud adalah lulusan yang } \\
\text { dipersiapkan untuk memasuki } \\
\text { perguruan tinggi atau } \\
\text { dipersiapkan untuk memasuki } \\
\text { dunia kerja. }\end{array}$ \\
\hline Bakat dan Minat & $\begin{array}{l}\text { Bakat dan minat yang } \\
\text { dimaksud adalah memilih } \\
\text { sekolah sesuai dengan bakat } \\
\text { yang dimiliki oleh anak } \\
\text { tersebut. }\end{array}$ \\
\hline
\end{tabular}

Tabel 3. Matriks Perbandingan Berpasangan Kriteria Utama

\begin{tabular}{|l|l|l|l|l|}
\hline Kriteria & Biaya & $\begin{array}{l}\text { Kualitas } \\
\text { Sekolah }\end{array}$ & $\begin{array}{l}\text { Tujuan } \\
\text { Akhir } \\
\text { Lulusan }\end{array}$ & $\begin{array}{l}\text { Bakat } \\
\text { dan } \\
\text { Minat }\end{array}$ \\
\hline Biaya & 1,000 & 0,670 & 0,964 & 1,445 \\
\hline $\begin{array}{l}\text { Kualitas } \\
\text { Sekolah }\end{array}$ & 1,493 & 1,000 & 1,249 & 2,012 \\
\hline $\begin{array}{l}\text { Tujuan } \\
\text { Akhir } \\
\text { Lulusan }\end{array}$ & 1,037 & 0,801 & 1,000 & 1,373 \\
\hline $\begin{array}{l}\text { Bakat } \\
\text { dan } \\
\text { Minat }\end{array}$ & 0,692 & 0,497 & 0,728 & 1,000 \\
\hline
\end{tabular}

Tabel 4.Matriks Perbandingan Kriteria Biaya

\begin{tabular}{|l|l|l|l|}
\hline Kriteria & SMA & SMK & MA \\
\hline SMA & 1,000 & 0,775 & 1,524 \\
\hline SMK & 1,290 & 1,000 & 1,484 \\
\hline MA & 0,656 & 0,674 & 1,000 \\
\hline
\end{tabular}

Tabel 5. Matriks Perbandingan Kriteria Kualitas Sekolah

\begin{tabular}{|l|l|l|l|}
\hline Kriteria & SMA & SMK & MA \\
\hline SMA & 1,000 & 1,111 & 1,101 \\
\hline SMK & 0,900 & 1,000 & 1,093 \\
\hline MA & 0,908 & 0,915 & 1,000 \\
\hline
\end{tabular}

Tabel 6.Matriks Perbandingan Kriteria Tujuan Akhir Lulusan

\begin{tabular}{|c|c|c|c|}
\hline Kriteria & SMA & SMK & MA \\
\hline SMA & 1,000 & 1,055 & 1,895 \\
\hline SMK & 0,948 & 1,000 & 2,007 \\
\hline MA & 0,528 & 0,498 & 1,000 \\
\hline
\end{tabular}

Tabel 7. Matriks Perbandingan Kriteria Bakat dan Minat

\begin{tabular}{|l|l|l|l|}
\hline Kriteria & SMA & SMK & MA \\
\hline SMA & 1,000 & 1,157 & 1,801 \\
\hline SMK & 0,864 & 1,000 & 1,780 \\
\hline MA & 0,555 & 0,562 & 1,000 \\
\hline
\end{tabular}

Tabel 8. Selisih Nilai Eigen Vector Kriteria Utama Iterasi Ke-1 \& Iterasi Ke-2

\begin{tabular}{|l|l|l|}
\hline \multicolumn{2}{|l|}{ Nilai Eigen } & \multirow{2}{*}{ Selisih } \\
\cline { 1 - 2 } Iterasi ke-1 & Iterasi ke-2 & \\
\hline 0,23871 & 0,23874 & $-0,00003$ \\
\hline 0,33830 & 0,33821 & 0,00009 \\
\hline 0,25117 & 0,25117 & $-0,00001$ \\
\hline 0,17182 & 0,17188 & $-0,00005$ \\
\hline
\end{tabular}

Tabel 9. Selisih Nilai Eigen Vector Kriteria Utama Iterasi Ke-2 \& Iterasi Ke-3

\begin{tabular}{|l|l|l|}
\hline \multicolumn{2}{|l|}{ Nilai Eigen } & \multirow{2}{*}{ Selisih } \\
\cline { 1 - 2 } Iterasi ke-2 & Iterasi ke-3 & \\
\hline 0,23874 & 0,23874 & 0,00000 \\
\hline 0,33821 & 0,33821 & 0,00000 \\
\hline 0,25117 & 0,25117 & 0,00000 \\
\hline 0,17188 & 0,17188 & 0,00000 \\
\hline
\end{tabular}

Tabel 10. Selisih Nilai Eigen Vector Kriteria Biaya Iterasi Ke-1 \& Iterasi Ke-2

\begin{tabular}{|l|l|l|}
\hline \multicolumn{2}{|l|}{ Nilai Eigen } & \multirow{2}{*}{ Selisih } \\
\cline { 1 - 2 } Iterasi ke-1 & Iterasi ke-2 & \\
\hline 0,34538 & 0,34537 & $-0,00002$ \\
\hline 0,40594 & 0,40572 & 0,00022 \\
\hline
\end{tabular}




\begin{tabular}{|l|l|l|}
\hline 0,24868 & 0,24891 & $-0,00023$ \\
\hline
\end{tabular}

Tabel 11.Selisih Nilai Eigen Vector Kriteria Biaya Iterasi Ke-2 \& Iterasi Ke-3

\begin{tabular}{|l|l|l|}
\hline \multicolumn{2}{|l|}{ Nilai Eigen } & \multirow{2}{*}{ Selisih } \\
\cline { 1 - 2 } Iterasi ke-2 & Iterasi ke-3 & \\
\hline 0,34537 & 0,34537 & 0,00000 \\
\hline 0,40572 & 0,40572 & 0,00000 \\
\hline 0,24891 & 0,24891 & 0,00000 \\
\hline
\end{tabular}

Tabel 12. Selisih Nilai Eigen Vector Kualitas

Sekolah Iterasi Ke-1 \& Iterasi Ke-2

\begin{tabular}{|l|l|l|}
\hline \multicolumn{2}{|l|}{ Nilai Eigen } & \multirow{2}{*}{ Selisih } \\
\cline { 1 - 2 } Iterasi ke-1 & Iterasi ke-2 & \\
\hline 0,35600 & 0,35599 & 0,00001 \\
\hline 0,33106 & 0,33106 & 0,00000 \\
\hline 0,31294 & 0,31295 & $-0,00001$ \\
\hline
\end{tabular}

Tabel 13. Selisih Nilai Eigen Vector Kualitas

Sekolah Iterasi Ke-2 \& Iterasi Ke-3

\begin{tabular}{|l|l|l|}
\hline \multicolumn{2}{|l|}{ Nilai Eigen } & \multirow{2}{*}{ Selisih } \\
\cline { 1 - 2 } Iterasi ke-2 & Iterasi ke-3 & \\
\hline 0,35599 & 0,35599 & 0,00000 \\
\hline 0,33106 & 0,33106 & 0,00000 \\
\hline 0,31295 & 0,31295 & 0,00000 \\
\hline
\end{tabular}

Tabel 14. Selisih Nilai Eigen Vector Kriteria Tujuan Akhir Lulusan Iterasi Ke-1 \& Iterasi $\mathrm{Ke}-2$

\begin{tabular}{|l|l|l|}
\hline \multicolumn{2}{|l|}{ Nilai Eigen } & \multirow{2}{*}{ Selisih } \\
\hline Iterasi ke-1 & Iterasi ke-2 & \\
\hline 0,40129 & 0,40126 & 0,00003 \\
\hline 0,39470 & 0,39468 & 0,00002 \\
\hline 0,20401 & 0,20406 & $-0,00005$ \\
\hline
\end{tabular}

Tabel 15. Selisih Nilai Eigen Vector Kriteria Tujuan Akhir Lulusaan Iterasi Ke-2 \& Iterasi $\mathrm{Ke}-3$

\begin{tabular}{|l|l|l|}
\hline \multicolumn{2}{|l|}{ Nilai Eigen } & \multirow{2}{*}{ Selisih } \\
\cline { 1 - 2 } Iterasi ke-2 & Iterasi ke-3 & \\
\hline 0,40126 & 0,40126 & 0,00000 \\
\hline 0,39468 & 0,39468 & 0,00000 \\
\hline 0,20406 & 0,20406 & 0,00000 \\
\hline
\end{tabular}

Tabel 16. Selisih Nilai Eigen Vector Kriteria Bakat \& Minat (Iterasi Ke-1 \& Iterasi Ke-2)

\begin{tabular}{|l|l|l|}
\hline \multicolumn{2}{|l|}{ Nilai Eigen } & \multirow{2}{*}{ Selisih } \\
\cline { 1 - 2 } Iterasi ke-1 & Iterasi ke-2 & \\
\hline 0,41076 & 0,41071 & 0,00005 \\
\hline 0,37123 & 0,37121 & 0,00002 \\
\hline 0,21801 & 0,21808 & $-0,00007$ \\
\hline
\end{tabular}

Tabel 17. Selisih Nilai Eigen Vector Kriteria Bakat \& Minat (Iterasi Ke-2 \& Iterasi Ke-3)

\begin{tabular}{|c|c|c|}
\hline Nilai Eigen & & \\
\hline Iterasi ke-2 & Iterasi ke-3 & \\
\hline
\end{tabular}

\begin{tabular}{|l|l|l|}
\hline 0,41071 & 0,41071 & 0,00000 \\
\hline 0,37121 & 0,37121 & 0,00000 \\
\hline 0,21808 & 0,21808 & 0,00000 \\
\hline
\end{tabular}

consistency ratio Kriteria Utama

$$
C R=\frac{C I}{I R}=\frac{0,001}{0,90}=0,001
$$

Hasil dari $C R \leq 0,1$, maka hasil perhitungan dapat dinyatakan konsisten atau hasil dapat diterima.

consistency ratio Kriteria Biaya

$$
C R=\frac{C I}{I R}=\frac{0,004}{0,58}=0,008
$$

Hasil dari $C R \leq 0,1$, maka hasil perhitungan dapat dinyatakan konsisten atau hasil dapat diterima.

consistency ratio Kriteria Kualitas Sekolah

$$
C R=\frac{C I}{I R}=\frac{0,001}{0,58}=0,001
$$

Hasil dari $C R \leq 0,1$, maka hasil perhitungan dapat dinyatakan konsisten atau hasil dapat diterima.

consistency ratio Kriteria Akhir Lulusan

$$
C R=\frac{C I}{I R}=\frac{0,001}{0,58}=0,001
$$

Hasil dari $C R \leq 0,1$, maka hasil perhitungan dapat dinyatakan konsisten atau hasil dapat diterima.

consistency ratio Kriteria Bakat dan Minat

$$
C R=\frac{C I}{I R}=\frac{0,001}{0,58}=0,001
$$

Hasil dari $C R \leq 0,1$, maka hasil perhitungan dapat dinyatakan konsisten atau hasil dapat diterima.

Berikut struktur hirarki penilaian bobot dari masing-masing kriteria dan masing-masing alternatif:

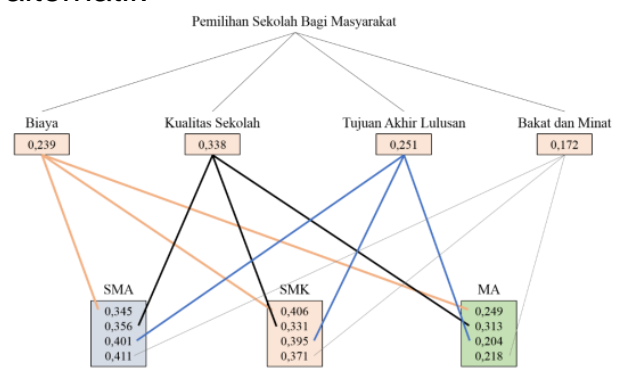

Gambar 3. Struktur Hirarki Hasil Perhitungan

Setelah dilakukan perhitungan data dari kriteria utama dan alternatif, selanjutnya 
dilakukan perhitungan perkalian gabungan antara kriteria dengan masing-masing alternatif berdasarkan kriteria, perhitungan tersebut dilakukan dengan cara mengalikan gabungan nilai vektor eigen masing-masing alternatif utama berdasarkan kriteria dengan nilai vektor eigen kriteria utama dan hasil dari perkalian tersebut disebut dengan nilai vektor eigen keputusan. Berikut adalah cara perhitungan untuk menentukan nilai vektor eigen keputusan:

$$
\begin{aligned}
& {\left[\begin{array}{llll}
0,345 & 0,356 & 0,401 & 0,411 \\
0,406 & 0,331 & 0,395 & 0,371 \\
0,249 & 0,313 & 0,204 & 0,218
\end{array}\right] \times\left[\begin{array}{l}
0,239 \\
0,338 \\
0,251 \\
0,172
\end{array}\right]} \\
& =\left[\begin{array}{l}
0,374 \\
0,372 \\
0,254
\end{array}\right]
\end{aligned}
$$

Tabel 18. Hasil Akhir Perhitungan

\begin{tabular}{|l|l|}
\hline SMA & 0,374 \\
\hline SMK & 0,372 \\
\hline MA & 0,254 \\
\hline
\end{tabular}

Dari nilai vektor eigen keputusan terlihat bahwa:

1. SMA (Sekolah Menengah Atas) memiliki prioritas tertinggi dengan bobot 0,374 atau $37,4 \%$.

2. SMK(Sekolah Menengah Kejuruan) memiliki prioritas kedua dengan bobot 0,372 atau $37,2 \%$.

3. MA (Madrasah Aliyah) memiliki prioritas terendah dengan bobot 0,254 atau $25,4 \%$.

Selanjutnya dilakukan perhitungan akhir yaitu menghitung Rasio Konsistensi Hirarki $(\mathrm{CRH})$ dengan cara sebagai berikut:

$$
\begin{aligned}
& \mathrm{CRH}=\frac{\mathrm{M}}{\mathrm{M}^{\prime}} \\
& \text { a. } \mathrm{M}=\mathrm{Cl} \text { kriteria + (vektor eigen } \\
& \text { kriteria) } x \text { (Cl alternatif) } \\
& \left.\begin{array}{llll}
0,239 & 0,338 & 0,251 & 0,172
\end{array}\right] \times\left[\begin{array}{l}
0,001+ \\
0,001 \\
0,001 \\
0,001
\end{array}\right] \\
& =0,001+0,001 \\
& =0,003 \\
& \text { b. } \quad \mathrm{M}^{\prime}=\mathrm{RI} \text { kriteria + (vektor eigen } \\
& \text { kriteria) } \times(\mathrm{RI} \text { alternatif) } \\
& \left.\begin{array}{cccc}
= & 0,90+ \\
0,239 & 0,338 & 0,251 & 0,172
\end{array}\right] \times\left[\begin{array}{c}
0,58 \\
0,58 \\
0,58 \\
0,58
\end{array}\right] \\
& =0,90+0,58 \\
& =1,48
\end{aligned}
$$

c. Perhitungan $\mathrm{CRH}$ :

$$
\begin{aligned}
& \quad \text { CRH }=\frac{M}{M^{\prime}} \\
& =\frac{0,003}{1,48} \\
& =0,002
\end{aligned}
$$

Dari perhitungan diatas didapatkan bahwa nilai $\mathrm{CRH}$ kurang dari 0,1 atau kurang dari $10 \%$, maka dapat dinyatakan bahwa hirarki secara keseluruhan bersifat konsisten atau dapat diterima, sehingga keputusan ditetapkan dapat diandalkan dan hasil yang telah diperoleh sesuai dengan hasil hipotesis.

\section{Kesimpulan}

Berdasarkan hasil analisa dan pengolahan data yang telah dilakukan oleh penulis selama penelitian, maka dapat diambil kesimpulan sebagai berikut:

1. Pertimbangan-pertimbangan atau kriteria yang telah ditentukan dalam penelitian ini didapatkan dari hasil wawancara dan terdapat empat kriteria diantaranya yaitu, Kriteria Biaya, Kriteria Kualitas Sekolah, Kriteria Tujuan Akhir Lulusan, dan Kriteria Bakat dan Minat yang menjadi tolak ukur dalam melakukan pemilihan sekolah.

2. Hasil dari pengolahan data dan pengujian berdasarkan perhitungan metode Analytical Hierarchy Process didapatkan bahwa kriteria Kualitas Sekolah menjadi kriteria tertinggi pada pemilihan sekolah. Kemudian Sekolah Menengah Atas (SMA) lebih unggul 0,373 atau $37,3 \%$ sedangkan Sekolah Menengah Kejuruan (SMK) 0,370 atau $37,0 \%$, Madrasah Aliyah (MA) 0,257 atau $25,7 \%$.

\section{Referensi}

Akmaludin. (2015). Multi Criteria Analysis Menentukan Point Weight Comparation Dalam Penetapan Decision Priority. Jurnal Pilar Nusa Mandiri, XI No.1(Maret 2015, ISSN: 1978-1946), 11-19.

Akmaludin. (2015). Teknik Penyeleksian Keputusan Menggunakan Analytic Hierarchy Process Pada Proyek Portofolio. Jurnal Pilar Nusa Mandiri, XI No. 2(September 2015, ISSN: 1978-1946), 102-111.

Basuki, Ari dan Andharini Dwi Cahyani. (2016). Sistem Pendukung 
Keputusan. Yogyakarta: Deepublish.

Frieyadie. (2017). Penerapan Metode Ahp Sebagai Pendukung Keputusan Penetapan Beasiswa. Jurnal Pilar Nusa Mandiri, 13 No. 1(Maret 2017, ISSN: 1978-1946 \& E-ISSN: 25276514), 49-58.

Hadianti, S., \& Mubarok, A. (2017). Sistem Pendukung Keputusan Pemilihan Mata Pelajaran Unggulan Pada LPI Al-Muhajirin Cibeurih. Jurnal Informatika, 4 No. 1(April 2017, ISSN: 2355-6579 \& E-ISSN: 25282247), 103-107.

Handayani, R. I. (2015). Pemanfaatan Aplikasi Expert Choice Sebagai Alat Bantu Dalam Pengambilan Keputusan (Studi Kasus: PT . BIT Teknologi Nusantara). Jurnal Pilar Nusa Mandiri, XI No.1(Maret 2015, ISSN 1978-1946), 53-59.

Kusrini. (2016). Konsep dan Aplikasi Sistem Pendukung Keputusan. Yogyakarta: Andi.

Malik, A. Y., \& Haryanti, T. (2018). Penerapan Metode Analytical Hierarchy Process (AHP) Untuk Sistem Pendukung Keputusan Pemilihan Program Keahlian Pada SMK Daarul Ulum Jakarta. Jurnal Pilar Nusa Mandiri, 14 No. 1(Maret 2018, ISSN: 1978-1946 \& E-ISSN: 2527-6514), 123-130.

Marimin. (2015). Teknik dan Aplikasi Pengambilan Keputusan Kriteria Majemuk. Jakarta: Grasindo.

Narti. (2017). Pengambilan Keputusan Pemilihan Siswa Berprestasi
Menggunakan Metode AHP Dan Topsis. Jurnal Informatika, 4 No. 2(September 2017, ISSN: 23556579 \& E-ISSN: 2528-2247), 198205.

Nurmalasari, \& Pratama, A. A. (2018). Sistem Pendukung Keputusan Pemilihan Supplier Menggunakan Metode AHP Pada PT Transcoal Pacific Jakarta. Jurnal Teknik Komputer, IV No. 2(Agustus 2018, ISSN: 2442-2436 \& E-ISSN: 25500120), 48-55.

Pratiwi, Heny. (2016). Buku Ajar Sistem Pendukung Yogyakarta: Deepublish.

Rusman, A. (2016). Logika fuzzy Tahani Sistem Penunjang Keputusan Penentuan Lulusan Terbaik. Jurnal Informatika, III No. 1(April 2016, ISSN: 2355-6579), 31-40.

Sugiyono. (2016). Metode Penelitian Kuantitatif, Kualitatif, dan R\&D. Bandung: CV. Alfabeta.

Suryadi, Kadarsah, dan Muhammad Ali Ramdhani. (2017). Sistem Pendukung Keputusan Suatu Wacana Struktural Idealisasi dan Implementasi Konsep Pengambilan Keputusan. Bandung: PT. Remaja Rosdakarya Offset.

Warjiyono. (2015). Analisis Faktor Pemilihan Perguruan Tinggi Di Tegal Berdasarkan Jenjang Pendidikan Menggunakan Metode Analytical Hierarchy Process (AHP). Jurnal Evolusi, 3 No. 2(ISSN: 2338-8161), 33-38. 